\title{
FAP Gene Mutation
}

National Cancer Institute

\section{Source}

National Cancer Institute. FAP Gene Mutation. NCI Thesaurus. Code C118386.

A change in the nucleotide sequence of the FAP gene. 